\title{
IFAS's IPM, BMPs, FYN and More: An Alphabet Soup of Good Environmental Programs for Florida ${ }^{1}$
}

\section{J. Sonke and N. C. Leppla²}

The University of Florida Institute of Food and Agricultural Sciences (IFAS) has three related programs that often are confused within the IFAS community and by our clientele: Integrated Pest Management (IPM), Best Management Practices (BMPs), and Florida Yards and Neighborhoods (FYN).

The concept of IPM arose out of the need to protect against pests and diseases in an economically advantageous manner and with the least possible risk to the environment and human health. Thus, IPM was originally defined as "applied pest control which combines and integrates biological and chemical control. Chemical control is used as necessary and in a manner which is least disruptive to biological control. Integrated control may make use of naturally occurring biological control as well as biological control effected by manipulated or induced biotic agents" (Stern et al. 1959). The concept of BMPs, which came later, addressed the need to preserve the purity of water while still allowing land users to obtain the most benefit from it. An early use of the term was in the Clean Water Act of 1977, in which BMPs came to be defined as "practices or structures designed to reduce the quantities of pollutants -- such as sediment, nitrogen, phosphorus, and animal wastes
-- that are washed by rain and snow melt from farms into surface or ground waters." FYN is a very popular IFAS program that contains elements of both IPM and BMPs as they affect the urban landscape. FYN was initiated in 1994 to "help residents reduce pollution and enhance their environment by improving home and landscape management" (http://hort.ufl.edu/fyn/). All three of these programs are important for protecting Florida's fragile environments but differ in scope and structure for accomplishing their independent missions (Table 1).

The terms "IPM" and "BMPs" are frequently used interchangeably; however, the associated programs were developed to serve different purposes and do not share the same range of activities. IPM deals with the management of pests and diseases with minimal risk to human health or the environment, whereas BMPs focus on conserving water quality and preventing environmental pollution. IPM is a component of BMPs and FYN, and therefore narrower in scope. IPM is characterized by its tactics, including pest and disease prevention and management using a combination of cultural, biological, chemical and mechanical controls. BMPs and FYN focus on irrigation, fertilization, growing practices, and pest management. IPM and BMPs

1. This document is ENY-704, one of a series of the Department of Entomology and Nematology, Florida Cooperative Extension Service, Institute of Food and Agricultural Sciences, University of Florida. Publication date: November 2004. Please visit the EDIS Website at http://edis.ifas.ufl.edu.

2. D. J. Sonke, graduate student, Doctor of Plant Medicine Degree Program, and N. C. Leppla, professor and IPM Florida coordinator, Entomology and Nematology Department, Institute of Food and Agricultural Sciences, Gainesville, FL 32611.

The Institute of Food and Agricultural Sciences is an equal opportunity/affirmative action employer authorized to provide research, educational information and other services only to individuals and institutions that function without regard to race, color, sex, age, handicap, or national origin. For information on obtaining other extension publications, contact your county Cooperative Extension Service office. Florida Cooperative Extension Service/Institute of Food and Agricultural Sciences/University of Florida/Christine Taylor Waddill, Dean. 
apply to agriculture, communities and natural areas, while FYN is designed to address landscape and yard maintenance in residential communities. The statewide IFAS extension community provides considerable educational support to clientele groups of all three (Table 2).

\section{Allied UF/IFAS Agriculture, Community, and Natural Resources Programs}

Several other UF/IFAS programs have environmental protection as a focus. Because these programs are housed in various departments, they seldom are listed together in publications and may be difficult to identify as a group. Moreover, they have overlapping goals and complimentary activities. The following are UF/IFAS agriculture, community, and natural resources programs allied with IPM, FYN and BMPs are compiled as a reference (Table 3 ).

\section{Summary}

IPM, BMPs, and FYN each have a related environmental orientation but differ in missions, objectives and delivery structures within IFAS's extension program. IPM Florida is a federally mandated IFAS program that addresses pest management in all of the state's environments. The IFAS BMP program provides research and extension coordination for agricultural production and management practices which vary by commodity and environment. FYN is an educational program that encourages resource conservation by homeowners and developers. Thus, although somewhat of an alphabet soup, the three distinct activities are pest management (IPM), pollution reduction in water (BMPs), and environmental landscape management (FYN). Each of them, and others in IFAS, contribute to the judicious use and protection of Florida's precious environments.

\section{References Cited}

Stern, V. M., R. F. Smith, R. van den Bosch, and K. S. Hagen. 1959. The integrated control concept. Hilgardia, 29: 81-101.
U.S. Clean Water Act, 1977, Sec. 319: National

Monitoring Program: Glossary. EPA Terminology

Reerence System, www.epa.gov/trs. 
Table 1. Comparison Summary of IPM Related Programs in IFAS.

\begin{tabular}{||l|l|l||}
\hline \hline \multicolumn{1}{||c||}{ IPM Florida } & \multicolumn{1}{|c||}{ Best Management Practices } & \multicolumn{1}{|c||}{ Florida Yards \& Neighborhoods } \\
\hline $\begin{array}{l}\text { IPM Florida provides statewide, } \\
\text { interdisciplinary and inter-unit } \\
\text { coordination and assistance in } \\
\text { integrated pest management to } \\
\text { protect agriculture, communities } \\
\text { and the environment. }\end{array}$ & $\begin{array}{l}\text { The IFAS BMP program serves as a } \\
\text { liaison between UF and state agencies } \\
\text { and grower organizations, oversees } \\
\text { development of BMPs, and coordinates } \\
\text { research and demonstration projects } \\
\text { around the state to enhance water quality } \\
\text { and natural resources. }\end{array}$ & $\begin{array}{l}\text { FYN provides special educational and } \\
\text { outreach activities directed at the } \\
\text { community to help residents reduce } \\
\text { pollution and enhance their } \\
\text { environment by improving home and } \\
\text { landscape management. }\end{array}$ \\
\hline \hline
\end{tabular}

Table 2. The role of IPM, BMPs and FYN.

\begin{tabular}{|c|c|}
\hline \multicolumn{2}{|r|}{ IPM Florida } \\
\hline Emphasis: & $\begin{array}{l}\text { Effective and sustainable management of pests through use of all available tools: } \\
\text { prevention techniques and cultural, biological, chemical, and physical controls. }\end{array}$ \\
\hline Structure: & $\begin{array}{l}\text { An IFAS program, consisting of the IPM Coordinator and full and part-time staff, which } \\
\text { also functions as the Florida component of the Southern Region IPM Center and the } \\
\text { National IPM Network. }\end{array}$ \\
\hline Primary Clientele: & $\begin{array}{l}\text { County extension faculty throughout Florida with agricultural, community, and natural } \\
\text { resource clientele. }\end{array}$ \\
\hline Funding: & $\begin{array}{l}\text { Federal IPM monies (Smith-Lever [section } 3(\mathrm{~d})] \text { ) with additional support from IFAS and } \\
\text { competitive grants. }\end{array}$ \\
\hline Benefits: & $\begin{array}{l}\text { Provides effective and economical pest management with use of fewer and lower risk } \\
\text { pesticides to protect human health and the environment. }\end{array}$ \\
\hline Contact Information: & $\begin{array}{l}\text { Norman C. Leppla, Ph.D. } \\
\text { Professor and Program Director, IPM } \\
\text { PO Box } 110620 \\
\text { Bldg. } 970, \text { Natural Area Drive } \\
\text { Gainesville, FL } 32611 \\
\text { Ph: 352-392-1901 x120 } \\
\text { Fax: 352-392-0190 } \\
\text { E: ncleppla@ifas.ufl.edu } \\
\text { http://ipm.ifas.ufl.edu }\end{array}$ \\
\hline \multicolumn{2}{|r|}{ IFAS BMPs Program } \\
\hline Emphasis: & $\begin{array}{l}\text { Protection of surface and ground water resources through careful management of } \\
\text { potential sources of pollution, including, irrigation, fertilization, animal wastes, pesticides, } \\
\text { etc. }\end{array}$ \\
\hline Structure: & $\begin{array}{l}\text { An IFAS program which coordinates research, demonstrations and educational } \\
\text { programs conducted throughout the state. The goals of these programs are to increase } \\
\text { environmental awareness, assist landowners in selecting and implementing appropriate } \\
\text { BMPs, monitor BMP effectiveness, reduce non-point pollutant discharges, and enhance } \\
\text { water quality. }\end{array}$ \\
\hline Primary Clientele: & $\begin{array}{l}\text { County extension faculty throughout Florida with clientele in various agricultural and } \\
\text { horticultural industries. }\end{array}$ \\
\hline Funding: & Varies by commodity and region. \\
\hline
\end{tabular}


IFAS's IPM, BMPs, FYN and More: An Alphabet Soup of Good Environmental Programs for....

Table 2. The role of IPM, BMPs and FYN.

\begin{tabular}{|c|c|}
\hline Benefits: & Conservation and reduced pollution of ground and surface water. \\
\hline Contact Information: & $\begin{array}{l}\text { Brian J. Boman, Ph.D. } \\
\text { Associate Professor and Program Director, BMPs } \\
2199 \text { S Rock Rd. } \\
\text { Ft. Pierce, FL } 34945 \\
\text { Ph: } 772-468-3922 \text { x122 } \\
\text { Fax: } 772-460-3648 \\
\text { E: bjboman@ifas.ufl.edu }\end{array}$ \\
\hline \multicolumn{2}{|r|}{ Florida Yards and Neighborhoods (FYN) } \\
\hline Emphasis: & $\begin{array}{l}\text { Special educational and outreach activities in landscape design and management to } \\
\text { reduce stormwater runoff, decrease non-point source pollution, conserve water, } \\
\text { enhance wildlife habitat, and create beautiful landscapes. }\end{array}$ \\
\hline Structure: & $\begin{array}{l}\text { An IFAS program implemented by county extension faculty coordinated in partnership } \\
\text { with the Florida Department of Environmental Protection (DEP) and other agencies in } \\
\text { the public and private sector. }\end{array}$ \\
\hline Primary Clientele: & Homeowners and communities throughout Florida \\
\hline Funding: & Support from IFAS and competitive grants from Florida DEP and other partner agencies. \\
\hline Benefits: & $\begin{array}{l}\text { Protection and conservation of water resources; use of fewer and lower risk materials } \\
\text { maintemance materials and practices in urban landscapes. }\end{array}$ \\
\hline Contact Information: & $\begin{array}{l}\text { Barbara C. Larson, Ph.D. } \\
\text { Statewide Coordinator } \\
\text { Florida Yards \& Neighborhoods } \\
\text { Environmental Horticulture Department } \\
\text { PO Box } 110675 \\
\text { Gainesville, FL } 32611 \\
\text { Ph: 352-392-1831 x330 } \\
\text { Fax: 352-392-1413 } \\
\text { E: bclarson@ifas.ufl.edu } \\
\text { http://hort.ufl.edu/fyn/ }\end{array}$ \\
\hline
\end{tabular}

Table 3. Allied UF/IFAS Agriculture, Community, and Natural Resources Programs

\begin{tabular}{||l|l||}
\hline \hline Joan A. Dusky, Ph.D. & Michael S. Spranger, Ph.D. \\
Assistant Dean for Extension - Agricultural Programs & Assistant Dean for Extension - Aquatic, Coastal and \\
1038 McCarty Hall & Aquaculture Programs and Natural Resources \\
PO Box 110210 & Bldg. 803 \\
Gainesville, FL 32611 & PO Box 110405 \\
Ph: 352-392-1761x229 & Gainesville, FL 32611 \\
Fax: 352-846-0458 & Ph: 352-392-1837 x226 \\
E: jadu@ifas.ufl.edu & Fax: 352-392-5113 \\
& E: msspranger@ifas.ufl.edu \\
\hline \hline
\end{tabular}


Table 3. Allied UF/IFAS Agriculture, Community, and Natural Resources Programs

\begin{tabular}{|c|c|}
\hline $\begin{array}{l}\text { Center for Aquatic and Invasive Plants } \\
\text { Randall K. Stocker, Ph.D., Director } \\
7922 \text { N.W. } 71 \text { st Street } \\
\text { PO Box } 110610 \\
\text { Gainesville, FL } 32653 \\
\text { Ph: 352-392-9613 } \\
\text { Fax: 352-392-3462 } \\
\text { E: aqplants@ifas.ufl.edu } \\
\text { http://plants.ifas.ufl.edu/ } \\
\text { The mission of the Center for Aquatic and Invasive Plants is } \\
\text { to provide a coordinated, statewide aquatic and invasive } \\
\text { plant research and extension program examining plant } \\
\text { production, distribution, ecology, and biology, while } \\
\text { emphasizing management techniques and strategies. }\end{array}$ & $\begin{array}{l}\text { Florida Master Gardener Program } \\
\text { Tom A. Wichman, Coordinator } \\
107 \text { Mehrhof Hall } \\
\text { PO Box } 110675 \\
\text { Gainesville, FL } 32611 \\
\text { Ph: } 352-392-1831 \text { x331 } \\
\text { E: twichman@ifas.ufl.edu } \\
\text { http://hort.ufl.edu/mg/ } \\
\text { Florida Master Gardeners are volunteer teachers trained } \\
\text { by county extension faculty. Master Gardeners educate } \\
\text { and provide research-based information to Floridians } \\
\text { about gardening, America's most popular pastime. Their } \\
\text { information about planning and maintaining urban, } \\
\text { suburban, and rural landscapes always emphasizes } \\
\text { environmental stewardship. }\end{array}$ \\
\hline $\begin{array}{l}\text { Center for Organic Agriculture } \\
\text { Rose L. Koenig, Ph.D., Co-director } \\
\text { Mickie Swisher, Ph.D., Co-director } \\
3026 \text { McCarty Hall } \\
\text { P.O. Box } 110310 \\
\text { Gainesville, FL } 32611 \\
\text { Ph: } 352-392-1987 \text { x267 } \\
\text { E: rlkoenig@ifas.ufl.edu } \\
\text { The goals of the Center are to: (1) facilitate } \\
\text { multi-disciplinary, multi-institutional research programs that } \\
\text { will provide the scientific basis for organic food and fiber } \\
\text { production; (2) collate and disseminate science-based } \\
\text { information about organic farming principles and practices } \\
\text { from UF/IFAS, other land grant institutions, the USDA and } \\
\text { other research institutions; and (3) incorporate an } \\
\text { appropriate focus on organic production practices and } \\
\text { processes in current and new courses offered by the } \\
\text { University of Florida. }\end{array}$ & $\begin{array}{l}\text { Florida Master Naturalist Program } \\
\text { Martin B. Main, Ph.D., Program Leader } \\
2686 \text { SR } 29 \text { N } \\
\text { Immokalee, FL } 34142 \\
\text { Ph: 239-658-3400 } \\
\text { Fax: 239-658-3469 } \\
\text { E: info@masternaturalist.org } \\
\text { http://www.masternaturalist.ifas.ufl.edu/ } \\
\text { The FMNP is an adult education extension program } \\
\text { developed by UF and provided by participating } \\
\text { organizations. FMNP training will benefit persons } \\
\text { interested in learning more about Florida's environment, } \\
\text { seeking educational contact hours, or wishing to } \\
\text { increase their knowledge for use in education programs } \\
\text { as volunteers, employees and ecotourism guides. }\end{array}$ \\
\hline
\end{tabular}


Table 3. Allied UF/IFAS Agriculture, Community, and Natural Resources Programs

\begin{tabular}{|c|c|}
\hline $\begin{array}{l}\text { Center for Tropical Agriculture } \\
\text { Waldemar Klassen, Ph.D., Director } \\
18905 \text { SW 280th Street } \\
\text { Homestead, FL } 33031 \\
\text { Ph: } 305-246-7001 \times 257 \\
\text { Fax: 305-246-7003 } \\
\text { E: klassen@ifas.ufl.edu } \\
\text { http://cta.ufl.edu/ } \\
\text { The mission of the Center is to conduct research, education } \\
\text { and extension programs intended to raise levels of nutrition } \\
\text { and standards of living of people in tropical and subtropical } \\
\text { regions, sustainably improve agricultural productivity and } \\
\text { natural resources management, protect and restore fragile } \\
\text { natural ecosystems potentially affected by agriculture, and } \\
\text { prevent loss of biodiversity. }\end{array}$ & $\begin{array}{l}\text { Pesticide Information Office } \\
\text { O. Norman Nesheim, Ph.D., Director } \\
\text { Building } 847 \text {, Hull Road } \\
\text { PO Box } 110710 \\
\text { University of Florida } \\
\text { Gainesville, FL } 32611 \\
\text { Ph: } 352-392-4721 \text { x201 } \\
\text { Fax: } 352-846-0206 \\
\text { E: onnesheim@ifas.ufl.edu } \\
\text { http://pested.ifas.ufl.edu/ } \\
\text { The PIO is charged with a variety of responsibilities, but } \\
\text { its overall function can be best described as assembling, } \\
\text { maintaining and disseminating current pesticide } \\
\text { information. A significant component is the IFAS } \\
\text { Pesticide Safety Education Program (PSEP), which } \\
\text { provides training and information to applicators on safe, } \\
\text { environmentally sound pesticide application practices, } \\
\text { personal safety and regulations. PSEP also assists } \\
\text { applicators in meeting state and federal certification and } \\
\text { licensing requirements to use pesticides in Florida. }\end{array}$ \\
\hline $\begin{array}{l}\text { Doctor of Plant Medicine Degree Program } \\
\text { Robert J. McGovern, Ph.D., Director } \\
1453 \text { Fifield Hall } \\
\text { P.O. Box } 110680 \\
\text { Gainesville, FL } 32611 \\
\text { Ph: } 352-392-3631 \text { x } 213 \\
\text { Fax: } 352-392-6532 \\
\text { E: rjm@ifas.ufl.edu } \\
\text { http://dpm.ifas.ufl.edu/ } \\
\text { The DPM degree is a unique professional, doctoral degree } \\
\text { analogous to the Doctor of Human Medicine (MD) and } \\
\text { Doctor of Veterinary Medicine (DVM) degrees. The } \\
\text { multidisciplinary program consists of courses and practical } \\
\text { training in all relevant departments (Agronomy, } \\
\text { Entomology/Nematology, Horticultural Sciences, Plant } \\
\text { Pathology, Soil and Water Science, etc.). }\end{array}$ & $\begin{array}{l}\text { School of Natural Resources and Environment } \\
\text { Randall K. Stocker, Ph.D. } \\
\text { Director of Research and Outreach } \\
1053 \text { McCarty Hall D } \\
\text { PO Box } 110230 \\
\text { Gainesville, FL } 32611 \\
\text { Ph: } 352-392-7622 \\
\text { Fax: } 352-846-2856 \\
\text { E: snre-mail@ufl.edu } \\
\text { http://snre.ufl.edu/ } \\
\text { The SNRE supports the University of Florida's } \\
\text { commitment to academic, research, outreach and } \\
\text { extension programs in ecology and environmental } \\
\text { sciences. Bringing together faculty from eleven different } \\
\text { UF programs, SNRE offers campus-wide, } \\
\text { interdisciplinary degree programs at both the } \\
\text { undergraduate and graduate levels. SNRE also } \\
\text { sponsors public outreach and extension programs, and } \\
\text { supports critical environmental research in a variety of } \\
\text { fields. }\end{array}$ \\
\hline
\end{tabular}


Table 3. Allied UF/IFAS Agriculture, Community, and Natural Resources Programs

\begin{tabular}{|c|c|}
\hline $\begin{array}{l}\text { Florida 4-H Youth Development Program } \\
\text { Marilyn N. Norman, Ph.D. } \\
\text { Assistant Dean for 4-H Youth Development } \\
3108 \text { McCarty Hall } \\
\text { P.O. Box } 110225 \\
\text { Gainesville, FL } 32611 \\
\text { Ph: } 352-846-0996 \times 225 \\
\text { Fax: } 352-846-0999 \\
\text { E: mnnorman@ifas.ufl.edu } \\
\text { http://4h.ifas.ufl.edu/ } \\
\text { 4-H is a non-formal educational program and an } \\
\text { organization for youth. Nationally, it is managed by the } \\
\text { Families, 4-H and Nutrition unit of the USDA CSREES. At } \\
\text { the state level, } 4 \text {-H is managed by UF/IFAS extension } \\
\text { through the extension faculty of participating counties. }\end{array}$ & $\begin{array}{l}\text { Southern Plant Diagnostic Network } \\
\text { Gail C. Wisler, Ph.D. } \\
\text { Chair, Plant Pathology } \\
1453 \text { Fifield Hall } \\
\text { PO Box } 110680 \\
\text { University of Florida } \\
\text { Gainesville, FL } 32611 \\
\text { Ph: 352-392-3631 x210 } \\
\text { Fax: 352-392-6532 } \\
\text { E: gcwisler@ifas.ufl.edu } \\
\text { http://spdn.ifas.ufl.edu/ } \\
\text { The NPDN was recently established by the USDA } \\
\text { CSREES to develop a network linking plant pest and } \\
\text { disease diagnostic facilities across the country. The } \\
\text { SPDN, located at UF/IFAS, is the Regional Center for } \\
\text { the Southern states and is charged with (1) establishing } \\
\text { a secure, regional network for the detection and } \\
\text { diagnosis of plant health problems, (2) extending and } \\
\text { supporting sound public policies, (3) implementing rapid } \\
\text { and accurate diagnoses and response strategies, and } \\
\text { providing leadership and training. }\end{array}$ \\
\hline $\begin{array}{l}\text { Florida Energy Extension Service } \\
\text { Pierce H. Jones, Ph.D., Director } \\
2610 \text { SW } 23 \text { Terrace, Bldg. } 242 \\
\text { PO Box } 110940 \\
\text { Gainesville, FL } 32611 \\
\text { Ph: 352-392-8074 } \\
\text { Fax: 352-392-9033 } \\
\text { E: ez@energy.ufl.edu } \\
\text { http://www.energy.ufl.edu/ } \\
\text { The FES works with professional audiences to promote } \\
\text { efficient use of energy and natural resources. FEES } \\
\text { programs include Florida Building Code Core Training, Build } \\
\text { Green \& Profit for building contractors, \$ell Green \& Profit for } \\
\text { real estate agents, and Hurricane Preparedness for Hotels } \\
\text { and Motels, and Hurricane Preparedness for } \\
\text { Condominiums. In addition to these, local University of } \\
\text { Florida Cooperative Extension Service offices conduct a } \\
\text { wide variety of related educational programs. }\end{array}$ & $\begin{array}{l}\text { Wetland Biogeochemistry Laboratory } \\
\text { Mark W. Clark, Ph.D. } \\
\text { Wetland Extension Specialist } \\
106 \text { Newell Hall } \\
\text { P.O. Box } 110510 \\
\text { Gainesville, FL } 32611 \\
\text { Ph: } 352-392-1803 \text { x319 } \\
\text { Fax: } 352-392-3399 \\
\text { E: clarkmw@ifas.ufl.edu } \\
\text { http://wetlandextension.ifas.ufl.edu/ } \\
\text { http://wetlands.ifas.ufl.edu/ } \\
\text { The WBL is a unit within the Soil and Water Science } \\
\text { Department at the University of Florida that promotes } \\
\text { excellence in teaching, research and extension/ outreach } \\
\text { activities on biogeochemical cycles in wetlands and } \\
\text { aquatic ecosystems. The primary goal of WBL is to } \\
\text { transfer basic research for solving practical problems, } \\
\text { and to integrate process level information into policy } \\
\text { development and regulation. }\end{array}$ \\
\hline
\end{tabular}

